\title{
Lightning through the Clouds
}


THIS PAGE INTENTIONALLY LEFT BLANK 


\section{Lightning through the Clouds}

'Izz al-Din al-Qassam and the

Making of the Modern Middle East

Mark Sanagan

University of Texas Press $\sqrt{ }$ Austin 
Copyright $\odot 2020$ by the University of Texas Press

All rights reserved

Printed in the United States of America

First edition, 2020

Requests for permission to reproduce material from this work should be sent to:

Permissions

University of Texas Press

P.O. Box 7819

Austin, TX 78713-7819

utpress.utexas.edu/rp-form

(®) The paper used in this book meets the minimum requirements of ANSI/NISO Z39.48-1992 (R1997) (Permanence of Paper).

Library of Congress Cataloging-in-Publication Data

Names: Sanagan, Mark, author.

Title: Lightning through the clouds : 'Izz al-Din al-Qassam and the making of the modern Middle East / Mark Sanagan.

Other titles: 'Izz al-Din al-Qassam and the making of the modern Middle East Description: First edition. | Austin : University of Texas Press, 2020. |

Includes bibliographical references and index.

Identifiers: LCCN 2019034301 | ISBN 978-1-4773-2056-3 (cloth) |

ISBN 978-1-4773-2058-7 (ebook) | ISBN 978-1-4773-2057-o (library ebook)

Subjects: LCSH: Qassām, 'Izz al-Dīn. | Ḥarakat al-Muqāwamah al-Islāmīyah. | Katā’ib 'Izz al-Dīn al-Qassām. | Revolutionaries-Palestine-Biography. | Jewish-Arab relationsHistory-1917-1948 - Biography. | Palestinian Arabs - Biography. | Palestine-

History-1917-1948. | Syria-History-French occupation, 1918-1946-Biography.

Classification: LCC DS125.3.Q36 S26 2020 | DDC 956.9404092 [в] - dc23

LC record available at https://lccn.loc.gov/2019034301

doi:10.7560/320563 